\title{
The Competitiveness of Master of Education Graduates: Porter's Diamond Analysis
}

\author{
https://doi.org/10.3991/ijet.v14i19.10767
}

Sukardi ( $\left.{ }^{\bowtie}\right)$, Rusdiawan and Lalu Ali Wardana

University of Mataram, West Nusa Tenggara, Indonesia

sukardi@unram.ac.id

\begin{abstract}
The competitiveness of university graduates is largely determined by its capacity to create and maintain competitive advantage. Based on the Porters' Diamond model, this study measures the competitive advantage of universities in Indonesia, especially the master's level of education. This model has almost never been in educational institutions, except for economic / business sectors. The data were collected through a survey and interpreted by the Porters' Diamond Compatibility Analysis. The competitiveness of master of education graduates in Indonesia is already in good level but is still considered low in the Southeast Asian level. Four factors of Porters' Diamond competitiveness have low supporting capacity so that it leads to the less competitiveness of the graduates. Strengthening the supporting capacity of demand conditions, educational relevance, and educational strategies are then becoming top priorities, including strengthening specific skills and developing sector-based competency.
\end{abstract}

Keywords - Competitiveness, Master of Education, Porter's Diamond.

\section{Introduction}

The quality and competitiveness level of university graduates in Indonesia are still low in international standard. This can be seen from the figure of some indexing agencies: Indonesia's Human Development Index (HDI) is 113 out of 188 countries [1], education quality is ranked 35 ([2], educational competitiveness is in 64 out of 113 countries surveyed [3]. From that indicator, it can be said that Indonesia is still left behind some countries in the region, such as Malaysia and Singapore. In fact, Indonesia has already had a quality standard called Indonesian Qualification Framework (IQF) which is considered at the same level as the Malaysian Qualification Framework (MQF) and European Qualification Framework (EQF). The use of this standard is important as the competitiveness of a nation or a region is very much dependent on the extent to which its institution succeeds in reaching international market [4]. In an economic perspective, product competitiveness (including graduates) in global markets is affected by relative competitiveness [5, 6]. Dwyer and Kim [7] also assert that product development (graduates) is highly dependent on its capacity to maintain a competitive advantage. 
In Porter's model $[8,9]$, competitive advantage is determined by four factors, namely: input factors, demand conditions, related and supporting industries, and firm strategy, structure and rivalry. Quite a lot of research uses this model to measure success in companies/ businesses, such as: the tourism sector in Portugal [4], and the tourism industry in Malaysia [10]. Not much research, however, uses Porter's competitive advantage model to measure success in the education sector. A research by Curran $[11,12]$ in the UK, for example, is still limited to the scope of the study rather than the entire spectrum of education. The relevance of this model is also due to the fact that some higher education institutions have a competitive advantage compared to other universities. Harvard University through its Route128, and National University of Singapore through its invention disclosure, patenting, technology licensing, and new venture spin-off [13] are the examples of high competitive universities.

In the context of education, input factors are related to availability of lecturers, educational infrastructure, capital or educational costs [8] including conformity with the regional context [6]. The input factor can be a predictor for the achievement of a qualified and competitive product (graduate) [11]. Demand conditions are related to market demand (users) to graduates. Competitive advantage will be achieved if educational institutions align their teaching and learning content with the need of markets/ users [9]. Related and supporting industries is related to the relevance of educational content to business world/ work world/ local superior sector [9]. This factor largely determines how an educational institution is organized and managed [12]. While firm strategy, structure and rivalry are linked to the national structure and strategy used in order to be more competitive. Those strategies will guide the educational institution to detect possible risks, and intervenes/ manipulates the conditions of demand. Thus, the use Porter's competitive advantage has as an evaluation tool to identify the level of competitiveness of higher education, and specifically at the masters of education level in Indonesia is badly needed.

\section{Research Methods}

In order to answer the research objective, this research uses Survey method which involves systematic, deep, and thorough analysis of the information [14]. The research population is all graduates of Master of Education Programs of Mataram University, who graduated from Master of Educational Administration (MEA), Master of Natural Sciences Education (MNSE), Master of English Education (MEE), and Master of Indonesian Language Education (MILE). Based on the data, there were 409 graduates of those programs in 2016. Slovin formulation is used to select the 205 samples; 124 male graduates and 79 female graduates [15]. The selection of the samples was conducted randomly.

The data collection instruments used are questionnaires combined with indepth interviews, and document review. The questionnaire for competitiveness is developed based on the four competitive advantage factors of Porter $[8,9]$. The questionnaire is formulated in Likert scale with 4 options $(1=$ very bad to $4=$ excellent). There are 4 
statement items (e.g. "lecturers teaching according to their competencies") related to input factors, 6 items (e.g. "market demand for graduates") related to condition of demand, 6 items (e.g. "Relevance of education to business / work needs"), and 3 items (e g "competencies built to support the development of a local flagship sector") related to relevance of education.

The graduates' competitiveness data were analyzed using quantitative descriptive technique, while the competitive compliance data were analyzed using Porter suitability analysis $[8,9]$. The competitive advantage (graduates' competitiveness) proposed by Porter is used as it is understood as the market behavior of the education industry, so that all four factors (input, demand conditions, relevance and educational strategy) should be met $[16,17]$. The conformity criteria used are: $<0.5$ (bad); $\geq 0.5-$ $<1.5$ (bad); $\geq 1.5-<2.5$ (doubtful); $\geq 2,5-<3.5$ (good); $\geq 3.5$ (very good).

\section{$3 \quad$ Results}

\subsection{Validity and reliability test results}

Internal consistency and reliability Test using Cronbach's $\alpha$ analysis with criteria exceeding 0.70 [18]. Based on the analysis as set in Table 1, all items of each tested aspects has met the criteria of internal consistency and reliability.

Table 1. Cronbach's Test Results $\alpha$ Intrument Research

\begin{tabular}{|l|c|c|}
\hline \multicolumn{1}{|c|}{ Aspects } & Number of Items & Cronbach $\boldsymbol{\alpha}$ \\
\hline Input Factor & 4 & .784 \\
\hline Demand Condition & 6 & .733 \\
\hline Relevance of Education & 4 & .881 \\
\hline Educational strategies & 3 & .764 \\
\hline
\end{tabular}

\subsection{Achievement of competitive advantage factors of master of education}

The result of Porter's Diamond analysis [8, 9], in general, the master of education has not fulfilled the four competitive advantage factors (Table 2 and Figure 1). 
Table 2. Achievement of Competitiveness Factors of the Graduates of Master of Education

\begin{tabular}{|c|c|c|c|}
\hline \multicolumn{2}{|c|}{ Supporting Factors of Competitiveness } & Score & Criteria \\
\hline \multirow{5}{*}{ Input factors } & $\begin{array}{l}\text { The teaching materials are relevant to lectures' } \\
\text { expertise }\end{array}$ & 2,46 & Doubtful \\
\hline & $\begin{array}{l}\text { The study program has administered pre-test to } \\
\text { identify students' learning needs }\end{array}$ & 3,03 & Good \\
\hline & $\begin{array}{l}\text { Education facilities and infrastructure meet } \\
\text { minimum service standards }\end{array}$ & 2,20 & Doubtful \\
\hline & $\begin{array}{l}\text { The existence of study program is in accordance } \\
\text { with the issue of local area/ potential }\end{array}$ & 2,17 & Doubtful \\
\hline & Average & 2,47 & Doubtful \\
\hline \multirow{7}{*}{$\begin{array}{l}\text { Demand } \\
\text { conditions }\end{array}$} & Market demand for graduates & 2,60 & Good \\
\hline & $\begin{array}{l}\text { The ability of companies / government } \\
\text { institutions / private institutions to provide jobs } \\
\text { for the graduates }\end{array}$ & 2,35 & Doubtful \\
\hline & $\begin{array}{l}\text { Graduates are easily recruited in the labor } \\
\text { market }\end{array}$ & 2,38 & Doubtful \\
\hline & $\begin{array}{l}\text { The jobs of alumni are in accordance with their } \\
\text { study background/ expertise }\end{array}$ & 2,71 & Good \\
\hline & Alumni have obtained business/ work contract & 2,74 & Good \\
\hline & Alumni get a job quickly & 2,27 & Doubtful \\
\hline & Average & 2,51 & Good \\
\hline \multirow{5}{*}{$\begin{array}{l}\text { Relevance of } \\
\text { Education }\end{array}$} & $\begin{array}{l}\text { Relevance of education to the needs of the } \\
\text { business world/ work }\end{array}$ & 2,25 & Doubtful \\
\hline & $\begin{array}{l}\text { Cooperation between the study program with } \\
\text { business actors/ world of work/ local } \\
\text { government agencies }\end{array}$ & 2,24 & Doubtful \\
\hline & $\begin{array}{l}\text { Existence of the study program is needed in this } \\
\text { area }\end{array}$ & 2,60 & Good \\
\hline & $\begin{array}{l}\text { The study program is easy to cooperate with } \\
\text { similar study program in Indonesia }\end{array}$ & 2,45 & Doubtful \\
\hline & Average & 2,39 & Doubtful \\
\hline \multirow{5}{*}{$\begin{array}{l}\text { Education } \\
\text { Strategy }\end{array}$} & $\begin{array}{l}\text { Competencies developed by the study program } \\
\text { are stated in national and regional government } \\
\text { missions }\end{array}$ & 2,73 & Good \\
\hline & $\begin{array}{l}\text { The competencies developed support the } \\
\text { development of the local flagship sector }\end{array}$ & 2,26 & Doubtful \\
\hline & This program often gets input from stakeholders & 2,36 & Doubtful \\
\hline & Average & 2,45 & Doubtful \\
\hline & Total & 2,45 & Doubtful \\
\hline
\end{tabular}




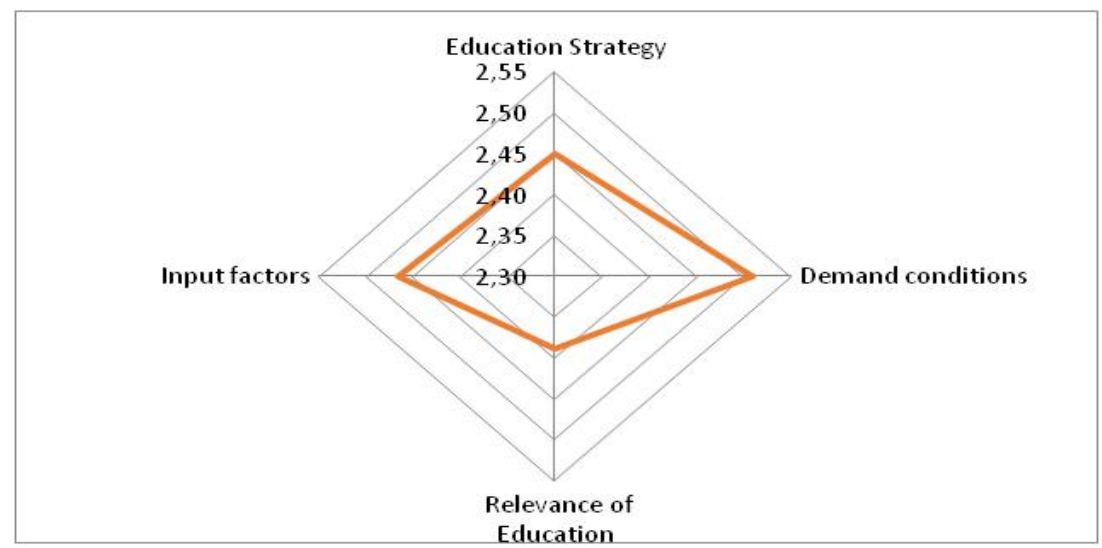

Fig. 1. Level of Porter's Diamond Competitiveness

From the data in Table 2 and Figure 1, it is shown that the supporting capacity of the Potter competitiveness factor is still low. Some points of deficiency, among others:

- Input: There is still disparity of lecturer's distribution and their topic is not relevant to their area of expertise especially: MEA and MILE, the existence of study program does not also meet the need of local government/potential issues (all study programs);

- Demand: The graduates have not been able to compete in Southeast Asia region, the ability of government/ business world to jobs is still low. This condition exists in all study programs that was allegedly due to socio-economic factors of Indonesia;

- Relevance of education: The competence of graduates developed quite in accordance with the expectations of government agencies, but still less in accordance with the business world and industry, including the issue of regional potential/ local advantage. This condition has implications for the competitiveness of graduates, especially in southeast asia and in the field of entrepreneurship; and

- Education strategy: In the context of the development of local and regional prioritized sectors, most of the pattern of development is relatively less appropriate.

Based on these findings, in the perspective of Potter, the graduates of master of education study program still have difficulties to compete unless the quality of the four factors mentioned above are improved.

\section{Discussion}

In the era of global competition, quantitative and qualitative changes, and increasing the role of human capital becomes an important factor in efforts to improve the quality of education in Higher Education [6]. In such international competition, higher education must be able to compete and show its superiority. To evaluate the 
quality and competitiveness, one aspect that needs to be taken into consideration is the opinion of the graduates on the level of competitiveness from the perspective of Porter's Diamond $[8,9]$. The results of this study show that the level of graduates' competitiveness is quite good at the national level, but is still low in the Southeast Asia level. One of the important findings is that little attention is paid to the practical side of the learning process, the use of information technology needed by the labor market, and the improvement of competencies that support local issues -based entrepreneurship. This condition is in line with the findings of Bikse et al. [6] which claim that the content of entrepreneurship education is still not based on prioritized sectors.

This study also shows the low supporting capacity of almost all components of the input factor, except for good input selection. The competence of lecturers as well as the availability of educational educational facilities also become the concern of alumni. In terms of educational background, lecturers are well educated as they are all graduated from doctorate program, but their expertise and the topics they teach are not linear. This will then lead to their weaknesses in content mastery, teaching strategy and personality. Indeed, the mastery of pedagogical aspect of the lecturers play important role in achieving learning outcomes [19] besides the soft skill mastery [20, 21].

Although demand conditions indicate better supporting capacity from market demand for graduates which can be seen from and high employment rate of the alumni, the supporting capacity of the corporate/ government to provide jobs for the labor force is still low. Porter [8] states that if domestic demand for products/ services is greater than abroad, then the firm should place greater emphasis on the development of a particular product/ service than a foreign company/ institution and create a competitive advantage in the domestic market.

Low supporting capacity is also shown in the relevance of education aspect. The cooperation of master of education study program with the industry in Indonesia, for example, is still weak. Porter [8] states that when industries (educational institutions) try to form industry support groups, they will achieve competitive advantage. Relevant support groups (industrial world/ local government) play an important role in technology transfer and innovation [22]. Thus, the access of Master of Education program to the industrial world/ work, similar study program, and including to the local government will encourage open ways of thinking and generate new ideas.

The last competitiveness factor is educational strategy or in broader terms according to Porter [8] called firm strategy, structure and rivalry. The results of the study indicate that only competence aspects are developed in accordance with national and regional government missions that receive good category responses. The implication is that educational institutions must be able to develop or create specific capabilities so as to adapt to a changing environment and maintain a competitive advantage. The criteria according to Ozgen's [23] study are specific competencies that are not easy to be duplicated by competitors. In this case, the potential of local advantages precisely become assets and strategic resources in the development of competence [24]. This potential is the capability differential of universities to achieve sustained competitive advantage $[25,26]$ 


\section{Conclusion}

The competitiveness of graduates of master of education is quite good in Indonesia, but is still low in Southeast Asia. The study finds that none of the graduates work abroad. The survey also shows that most of the respondents say that the education obtained does not have enough support to compete in the Southeast Asian labor market. In addition, the results of the study indicate that the four factors of competitive advantage proposed by Porter has a low supporting capacity which means that the mission to produce competitive graduates in the labor market has not yet been achieved. In short, it is necessary to reorganize the system and learning outcomes of master of education to meet Porter's competitive advantage. Strengthening competence towards the development of Indonesia and regional flagship sectors is the focus, including technical skills, such as language acquisition. Theoretically, the use of Porter's competitive advantage model in educational institutions is highly relevant and should be applied on higher education institutions to ensure customer satisfaction.

\section{References}

[1] UNDP. (2016). Human development report 2016. Retrieved from http://hdr.undp.org/sites/ default/files/HDR2016_EN_Overview_Web.pdf

[2] Global Competitive Index/GCI. (2018). The global competitiveness report 2017-2018: Quality of education. Retrieved from http://reports.weforum.org/pdf/gci-2017-2018scorecard/WEF_GCI_2017_2018_Scorecard_GCI.B.05.02.pdf

[3] UNESCO. (2015). The education for all development index. Retrieved from https://en.unesco.org/gem-report/node/888.

[4] Estevão, C., Nunes, S., Ferreira, J., \& Fernandes, C. (2018). Tourism sector competitiveness in Portugal: Applying Porter's Diamond (A competitividade do setor do turismo em Portugal: Aplicando o diamante de Porter). Tourism \& Management Studies, 14 (1), 30-44. https://doi.org/10.18089/tms.2018.14103

[5] Enright, M., \& Newton, J. (2005). Determinants of tourism destination competitiveness in Asia Pacific: comprehensiveness and universality. Journal of Travel Research, 43(4), 339350. https://doi.org/10.1177/0047287505274647

[6] Bikse, V., Rivẑa, B., \& Brence, I. (2013). Competiiveness and quality of higher education: Graduates' evaluation. Journal of teacher education for sustainability, 15 (2), 52-66. https://doi.org/10.2478/jtes-2013-0011

[7] Dwyer, L., \& Kim, C. (2003). Destination competitiveness: determinants and indicators. Current Issues in Tourism, 6 (5), 369-414. https://doi.org/10.1080/13683500308667962

[8] Porter, M. E. (1990). The competitive advantage of nations. Harvard Business Review, 68 (2), 73-83. https://doi.org/10.1002/cir.3880010112

[9] Porter, M. E. (1998). The competitive advantage of nations (with a new introduction by the author. Basingstoke: Macmillan. https://doi.org/10.1007/978-1-349-14865-3

[10] Lim, S. S. Y., Latip, H. A., \& Awang Marikan, D. A. (2013). Porter's Diamond Analysis on Competitiveness advantage of convention tourism: A case study on Sarawak convention tourism industry. Prosedding $2^{\text {nd }}$ Annual International Conference on Tourism and Hospitality Research (THoR): 52-61. https://doi.org/10.5176/2251-3426_THoR13.18 
[11] Curran, P. J. (2000). Competition in UK higher education: competitive advantage in the research assessment exercise and Porter's Diamond Model. Higher Education Quarterly, 54 (4), 386-410. https://doi.org/10.1111/1468-2273.00167

[12] Curran, P. J. (2001). Competition in UK higher education: applying Porter's diamond model to geography departments. Studies in Higher Education, 26 (2), 223-251. https://doi.org/10.1080/03075070120052125

[13] Wong, P. K., Ho, Y.P., \& Singh, A. (2007). Toward an "entrepreneurial university" model to support knowledge-based economic development: The case of the National University of Singapore. World Development, 35 (6), 941-958. https://doi.org/10.1016/ j.worlddev.2006.05.007

[14] Ary, D., Jacobs, L. C., \& Razavieh, A. (2010). Introduction to research in education (8ed). Belmont United State: Wadsworth/Thomson Learning Group.

[15] Tejada, J. J, \& Punzalan, J.R.B. (2012). On the MISUse of Slovin's formula. The Philippine Statistician, 61 (1), 129-136. Retrieved from http://www.psai.ph/ docs/publications/tps/tps_2012_61_1_9.pdf

[16] Liu, X., \& Mao, H. (2014). Analysis on problems of liaoning tourism industry based on Diamond Model. Applied Mechanics and Materials Vols, 651-653, 1527-1530. https://doi.org/10.4028/www.scientific.net/AMM.651-653.1527

[17] Mao, H., \& Liu, X. (2014). Analysis on coupling development competitiveness of tourism industry and modern service industry in liaoning province based on diamond model. Applied Mechanics and Materials Vols, 651-653, 1730-1733. https://doi.org/10.4028/ www.scientific.net/AMM.651-653.1730

[18] Nunnally, J. C. (1978). Psychometric theory (2 $2^{\text {nd }}$ ed.). New York: McGraw-Hill

[19] Ghina, A., Simatupang, T. M., \& Gustomo, A. (2017). The relevancy of graduates' competencies to the effectiveness of entrepreneurship education: a case study at SBM ITN - Indonesia. Journal of Entrepreneurship Education, 20 (1), 1-24. Retrieved from https://www.abacademies.org/articles/the-relevancy-of-graduates-competencies-to-theeffectiveness-of-entrepreneurship-education-a-case-study-at-sbm-itb--indonesia6570.html.

[20] Tang, K. N. (2018). The importance of soft skills acquisition by teachers in higher education institutions. Kasetsart Journal of Social Sciences, 30 (1), 1-6. https://doi.org/10. 1016/j.kjss.2018.01.002

[21] Polnaya, I., Nirwanto, N., \& Triatmanto, B. (2018). The evaluation of lecturer performance through soft skills, organizational culture and compensation on private University of Ambon. Academy of Strategic Management Journal, 17 (2), 1-9. Retrieved from https://www.abacademies.org/articles/The-evaluation-of-lecturer-performance-throughsoft-skills-1939-6104-17-2-200.pdf.

[22] Tan, J. (2006). Growth of industry clusters and innovation: lessons from beijing zhongguancun science park. Journal of Business Venturing, 21 (6), 827-850. https://doi.org/10.1016/j.jbusvent.2005.06.006

[23] Ozgen, E. (2011). Porter's Diamond Model and opportunity recognition: A cognitive perspective. Academy of Entrepreneurship Journal, 17 (2), 61-76. Retrieved from https://www.abacademies.org/articles/aejvol17no22011.pdf

[24] Bollinger, A. S., \& Smith, R. D. (2001). Managing organizational knowledge as a strategic asset. Journal of Knowledge Management, 5 (1), 8-18.https://doi.org/10.1108/136 $\underline{73270110384365}$

[25] Etzkowitz, H. (2004). The evolution of the entrepreneurial university. International Journal of Technology and Globalisation, 1 (1), 64-77. https://doi.org/10.1504/IJTG.2004.004551 
[26] Etzkowitz, H. (2013). Silicon Valley at risk? Sustainability of a global innovation icon: An introduction to the special issue. Social Science Information, 52 (4), 515-538. https://doi.org/10.1177/0539018413501946

\section{$7 \quad$ Authors}

Sukardi is Lecturer of the Faculty of Teachers Training and Education \& Postgraduate Program, University of Mataram, Indonesia. E-mail Id: sukardi@unram.ac.id

Rusdiawan is Lecturer of the Faculty of Teachers Training and Education, University of Mataram, Indonesia. E-mail Id: rusdiawan@live.com.

Lalu Ali Wardana is Lecturer of the Faculty of Teachers Training and Education, University of Mataram, Indonesia. E-mail Id: danmtr@yahoo.com.

Article submitted 2019-04-30. Resubmitted 2019-06-10. Final acceptance 2019-06-19. Final version published as submitted by the authors. 